\title{
Productization and Product Structure as the Backbone for Product Data and Fact-Based Analysis of Company Products
}

\author{
J. Harkonen ${ }^{1}$, E. Mustonen ${ }^{1}$, H. Hannila ${ }^{1}$ \\ ${ }^{1}$ Industrial Engineering and Management, University of Oulu, Oulu, Finland \\ (janne.harkonen@oulu.fi)
}

\begin{abstract}
Data are a strategic asset for companies but are not fully capitalized to serve the business. Company data assets that reside in the enterprise applications, the corporate business IT, have the potential to provide additional value aside serving the typical functional role of these applications. One possible application is the fact-based profitability analysis. Understanding company level or business line profitability is not enough for sustainable longterm business success, but product level analysis is needed. Currently product level analysis is often either seen not possible or entails laborious manual work. This study analyses the roles of productization and product structure as preconditions for fact-based analysis of company products. The study is realized as a combination of a literature review and analysis of eight companies. Those responsible for products and financial results may benefit of the understanding of the significance of productization and product structure for fact-based analysis and reporting on company products. The findings support data-driven approach and fact-based analysis.
\end{abstract}

Keywords - Productization, product structure, product data, fact-based analysis, product management, product profitability, data-driven approach, data assets, business IT.

\section{INTRODUCTION}

Decisions on company products are not always easy as they may involve big emotions [1], favorite products, or who shouts the loudest [2]. Companies may also rely too much on the highest paid person's opinion [3]. Hence, it is necessary to understand whether facts on products could be utilized. True fact-based analysis on company products might be desirable. Facts are necessary to understand which products are profitable, and which are worth keeping as they bring in profitable business [4].

Data are a strategic asset [5] that is being underutilized by companies. Trustworthy data are necessary for fact-based analysis and decisions. However, the use of data is complicated by too much data negatively impacting information reliability as it takes time to locate the needed data [6]. At the same time the amount of data is increasing rapidly [7]. Structure is needed for product-related data.

It is product master data that form the basis for factbased analysis of products. Product master data are created during product development and stored in an enterprise application [8]. Product-related business data, on the other hand, are necessary for transactions. They are product data with business process-related additional data. Also, customer, supplier, and vendor master data are valuable [9]. Product master data, product data, company business processes and the enterprise applications, the IT have been linked to a logical whole [9] [10]. However, as enterprise applications have been adopted from a functional or IT perspective, they risk becoming somewhat isolated [9] [11]. It can be said that master data act as the glue between products, processes and the enterprise applications.

Companies' enterprise applications may involve those used for design, enterprise resource planning (ERP), and customer relationship management (CRM), among others. The master data are often stored in a product data management system (PDM) [8]. Regardless of the application landscape, the master data must remain reliable, and unaltered to have value.

Consistent product structure is necessary for managing product master data through the product lifecycle [12]-[13]. Effective master data management necessitates structure [14]. This is regardless whether the product is physical, software, service, or any of their combination [12]. The product master data should remain unchanged through the product life-cycle from design until disposal [13]. Product structure has a role in organizing data by providing hierarchy to describe the product decomposition [4] [15]. Bill-of-Material (BOM) is a common product structure that identifies relations and reflect materials, assemblies, components, parts, and the quantities [16], the technical product composition. BOM structure is often used in PDM systems with added metadata. The master structure can reside in PDM, or in ERP and is transferred to other enterprise applications [9][17]. The enterprise applications, their integrations, and data transfer mechanisms may vary between companies.

The vertical product definition has been seen deficient in the product management literature, resulting in various interpretations of company products [4]. Therefore, [4] present commercial and technical product structures. If simplified, the commercial structure consists of product families, configurations and sales items, and the technical structure is formed through a version item. Product version changes due to quality improvements or cost reductions. Service type of products differ on the technical side and consist of processes, resources, and materials [15]. The commercial side should be familiar to marketing and sales, product management, and the customer interface. The technical side is familiar to product development, engineering, purchasing, logistics and suppliers [4]. Changes to the product can have impacts in a commercial sense, and in a technical sense 
[18]. Hence, it is vital that the commercial and technical structures are connected.

Productization links to the concept of product structure and relates to modelling of the offering according to a consistent product structure, commercially and technically [15]. Once logic is clear, the focus of productization is more on commercial side, the product configurations and sales items. It links to the value for customers and understanding of products. Division into commercial and technical product structure supports productization and vice versa [4] [19].

This study analyses the roles of productization and product structure as preconditions for fact-based analysis of company products. The necessity of understanding products and the roles of data, and enterprise applications are clarified.

\section{METHODOLOGY}

The purpose of this study is to enhance understanding of possibilities to utilize existing product data for factbased analysis of company products. Profitability is typically measured at a company level and the product level analysis requires excessive manual work. Prior understanding is limited; hence this study builds on qualitative case study design [20]. Since the topical area is multifaceted and the real-world context necessitates the experiences of industrial actors, a qualitative approach was appropriate. The method enables rich, in-depth and descriptive account. Table I shows the adopted approach.

The study involves reviewing extant literature and analyzing product-related practices in eight international companies. The companies were selected based on interests in product management, possibility to have access, and by avoiding competing business interests to avoid concealing of information. The companies represent $\mathrm{B} 2 \mathrm{~B}, \mathrm{~B} 2 \mathrm{C}, \mathrm{OEM}$, or combination type of businesses. The nature of their products is physical, software, service, or any combination.

The data collection includes semi-structured interviews [21]. The interviewees were asked about their understanding over products, amounts of products and their variations, understanding over share of profitable products, ability to measure profitability of individual sales items, the utilized product structures, and their consistency between different products. Also, product related data practices and the use of enterprise applications was covered.

Interviewees were selected based on the best possible knowledge on the interview topics. They were selected to represent different company functions to ensure versatile perspectives. The number of interviewees were fortyseven. The interviewee titles include heads of product management, IT, PLM, Marketing, NPD, R\&D, sales, operations, and business development, operations manager, PDM manager, application manager, product manager, product development manager, development specialist, project manager, and CEO. The interviews were recorded when allowed and notes were taken.
TABLE I

RESEARCH APPROACH

\begin{tabular}{|c|c|}
\hline Design & \\
\hline \multirow[t]{2}{*}{$\begin{array}{l}\text { Definition of } \\
\text { research questions }\end{array}$} & $\begin{array}{l}\text { How can consistency be reached for fact-based } \\
\text { product level analysis? }\end{array}$ \\
\hline & $\begin{array}{l}\text { How to reach fact-based analysis in siloed } \\
\text { enterprise application landscape? }\end{array}$ \\
\hline $\begin{array}{l}\text { Use of a priori } \\
\text { constructs, theory or } \\
\text { hypotheses }\end{array}$ & $\begin{array}{l}\text { Prior understanding of productization, product } \\
\text { structure, data and enterprise applications are } \\
\text { utilised for initial coding, No prior theory or } \\
\text { hypotheses specified. }\end{array}$ \\
\hline $\begin{array}{l}\text { Selection and } \\
\text { number of cases }\end{array}$ & $\begin{array}{l}\text { Criterion: Interests in product management, } \\
\text { Possibility of access, Inclusion of non-competing } \\
\text { companies to enable openness. }\end{array}$ \\
\hline Sampling & $\begin{array}{l}\text { Snowball sampling, interviewees added until } \\
\text { saturation. Number of companies influenced by } \\
\text { access to non-competing ones in Finland. }\end{array}$ \\
\hline \multicolumn{2}{|l|}{ Conduct } \\
\hline Data collection & $\begin{array}{l}\text { Semi-structured interviews, Company internal } \\
\text { data, Observation, Multiple investigators. }\end{array}$ \\
\hline \multicolumn{2}{|l|}{ Analysis } \\
\hline Entering field & $\begin{array}{l}\text { Overlapping data collection and analysis to make } \\
\text { necessary adjustments. }\end{array}$ \\
\hline Coding & $\begin{array}{l}\text { Thematic coding, first investigator individually } \\
\text { and then combined. Brief narratives created. Any } \\
\text { remarks kept separate. }\end{array}$ \\
\hline Logic & Inductive logic to allow the data to explain. \\
\hline Within-case analysis & $\begin{array}{l}\text { Understanding the context of individual } \\
\text { companies. }\end{array}$ \\
\hline Cross-case analysis & Search for patterns supported by interpretations \\
\hline Shaping hypotheses & Search for evidence across the data \\
\hline Testing hypotheses & Seminar with companies to validate \\
\hline
\end{tabular}

The data were classified according to themes by each interviewer after which the common understanding was confirmed to avoid bias. Supporting data included company internal materials. The analysis followed an inductive logic whereas the overall focus is pragmatic to a certain degree. Analytic generalization is attempted. Triangulation is fostered by a mixture of data and different researchers. Multiple, varying sources of data are utilized. Conclusions are drawn based on analyses, and implications are distilled. The findings were validated in a seminar arranged for the participating companies.

\section{RESULTS}

\section{A. Understanding over products and product profitability}

The interviewees' understanding over company products was queried in multiple ways to observe how consistently the products were understood. Based on the responses, it was rather clear that there was no consistent understanding of the products, or which elements belong to the product. The following interviewee quote illustrates this: "Product is not defined clearly and is currently assessed as the whole provided to customers". Some had difficulties in perceiving who the customer is: "Not clear who the customer is - end-customer vs. distributor". Variety of products seemed to be one factor. Configurability was also a source of confusion. Even though the technical side of the product (BOM) was managed to an extent, the consistency was lacking between products, or business units. Some did not perceive service as a product, but as something vague. 
TABLE II

PRODUCTS AND PROFITABILITY

\begin{tabular}{|c|c|c|c|c|c|c|}
\hline & \multicolumn{6}{|c|}{ Company \# } \\
\hline & 2 & 4 & 5 & 6 & 7 & 8 \\
\hline \# Products & \multicolumn{2}{|c|}{$\begin{array}{l}\text { No consistent } \\
\text { understanding. }\end{array}$} & \multicolumn{2}{|c|}{ Quite well understood. } & \multicolumn{2}{|c|}{$\begin{array}{l}\text { No consistent } \\
\text { understanding. }\end{array}$} \\
\hline \# Profitable & \multicolumn{2}{|c|}{$\begin{array}{c}\text { Information not } \\
\text { available with ease. }\end{array}$} & $\begin{array}{l}\text { Quite well } \\
\text { understood }\end{array}$ & \multicolumn{3}{|c|}{$\begin{array}{l}\text { Information not available with } \\
\text { ease. }\end{array}$} \\
\hline $\begin{array}{l}\text { Profitability } \\
\text { followed at }\end{array}$ & $\begin{array}{l}\text { Company } \\
\text { level. }\end{array}$ & $\begin{array}{c}\text { Contract } \\
\text { level. }\end{array}$ & $\begin{array}{l}\text { Company } \\
\text { level. }\end{array}$ & $\begin{array}{c}\text { Customer } \\
\text { level. }\end{array}$ & $\begin{array}{l}\text { Company } \\
\text { level. }\end{array}$ & $\begin{array}{c}\text { Delivery } \\
\text { level. }\end{array}$ \\
\hline $\begin{array}{l}\text { Costs } \\
\text { followed }\end{array}$ & \multicolumn{6}{|c|}{$\begin{array}{c}\text { Yes. } \\
\text { Systematics have room for improvement. }\end{array}$} \\
\hline $\begin{array}{l}\text { Sales } \\
\text { turnover } \\
\text { followed }\end{array}$ & \multicolumn{6}{|c|}{ Yes. } \\
\hline Sales items & \multicolumn{3}{|c|}{ Not particularly well followed. } & Followed. & \multicolumn{2}{|c|}{$\begin{array}{l}\text { Not particularly well } \\
\text { followed. }\end{array}$} \\
\hline $\begin{array}{l}\text { Profitability } \\
\text { of sales } \\
\text { items }\end{array}$ & \multicolumn{6}{|c|}{ Information not available with ease. } \\
\hline
\end{tabular}

Table II illustrates the company level findings on products and profitability.

Capabilities for product level analysis and reporting do not seem to exist in the companies. The inability for product level analysis seems to be due to challenges in data availability, sales and cost reporting structures. An interviewee commented: "The relevant information can be found, but systematic means for product profitability do not exist". The profitability was followed at company, customer, contract or delivery level. Sales item level analysis was seen to require manual work due to fragmented cost data, lack of systematics, and use of cost estimates. Finding 1: Common understanding of company products and systematics are necessary to have consistency for product level analysis.

\section{B. Productization and product structure}

The analyzed companies have deficiencies in how their products have been productized. This was evident as it was commonly not clear which elements should be considered as a part of the product. Evidence could not be found on consistent consideration of customer value.

The role of BOM is understood for the technical product structure, but the logic can be inconsistent between products or business lines. The technical structure was commented as: "For some products, we have a clear technical product structure, but this is not the case for all of our products". One company had modularized their newer products according to their assembly process, but challenges were experienced in consistency as the assembly process varied between products. Other one acknowledged the role of different views: "Technical product structure is considered and different BOM configurations are possible for design and manufacturing". One company utilized a generic technical structure. However, the technical structure was not fully covering in all companies: "product structure is missing elements, but the core is there". The role of version item as a representation of product versions was understood by some. This was also a source of challenges: "only one version item is possible at the time and causes challenges for production". The consistency in technical structure was seen possible along renewal of products but not for old products. Simultaneously killing of old products was seen challenging.

The product level analysis is challenged by the commercial product structure not always being known: "Consistent commercial product structure does not exist, but sales items are considered". Some companies had considered the commercial product structure, but there was no connection to the technical structure: "commercial and technical sides are somewhat isolated". One interviewee saw commercial and technical sides to be interwoven: "The commercial side has not been specified separately". However, the commercial structure seemed to be considered often in an isolated manner. Sales configuration was used by some, but this was not understood to relate to the commercial product structure. Some intended to utilize the commercial structure but had not started the implementation.

Product structure related terminology was not consistent and product configurations and sales items were not consistently considered as a part of commercial structure. The concept of sales item was mostly understood, with some variation in terminology: "Features [sales items] have been packaged to larger entities" - product configurations. Some created features based on software, but the differences were not visible in the sales items: "concrete approach is attempted by considering hardware". Companies has some variation in how sales items were seen: "sales items are considered as standard design items as the products are engineering to order type". This lack of considering products structurally, particularly commercially, clearly causes challenges. Only some acknowledged the nature of products in the commercial structure: "software is seen as a sales item", "Service is also included as a sales item". The overall commercial structure was often limited to sales items. Finding 2: Productization and product structure can be sources of consistency for fact-based product analysis. The commercial and technical structures must connect.

\section{Data and Enterprise applications}

Basic understanding on master data, business data, and other data such as IoT data are held by those whose responsibilities they link to in the companies. However, common consistent understanding on the overall logic did not seem to exist. The lack of overall understanding seems to relate to the existing landscape of enterprise applications, the IT systems. The overall logic is not considered as the landscape has developed over time.

Technical side of the product structure $(\mathrm{BOM})$ resides in product data management system (PDM) in many of the companies. Some have different BOM configurations in PDM. The companies also utilize design applications such as CAD. Product structure is often transferred from PDM to other applications: "PDM is the master, ERP is the slave". In some companies the role of PDM was vaguer. Interestingly, some had the most recent technical structure in ERP, even if PDM was supposed to have a 
central role. On the other hand, others did not have PDM at all but were working with ERP in terms of technical product structure. In these companies, the technical structure had more inconsistencies, or it had not been considered adequately.

Commercial product structure had room for improvement in terms of IT linkage in all the analyzed companies: "Commercial side is not acknowledged in IT systems, only sales items in PDM". Typically, it was the sales item level that was acknowledged the best, if the commercial side was considered. It was, however, obvious that the data related to commercial side were not managed consistently. The interviewees commented the linkage of sales items as follows: "Features [sales items] are missing in PDM", "No link to sales items".

Product configurations were considered by some: "Linking product configurations and the data has been started, but the person responsible left the company". The logic was, however, not clear for the commercial product structure. Some attempted configuring in ERP: "Products are configured in ERP as the PDM is not capable". This was interesting as the company did not have a clear commercial product structure. Focus was technical and it was clear that it was geared to ensure the fluent manufacturing operations. The challenges caused by the lack of clear commercial structure were evident: "Sales items have cost, but when two to three items are included, they cannot be compared". Some viewed the commercial considerations to link more to sales and therefore not as crucial: "We have sales configurator for sales, sales items are intended to link to the configurator".

CRM was utilized by some, but the commercial structure was not utilized: "Commercial structure is not linked to CRM". Others had limited use for CRM: "CRM used for service business only". One company used PIM to benefit commercial presentation. At the same time this company dealt with sales items only on commercial side and the same sales item had multiple codes.

Product master data resided in PDM in many cases, and product-related business data in ERP. However, some had all product-related master data in ERP. Customer master data were often in CRM, but not always:



Fig. 1. Productization and product structure form the backbone for data and fact-based analysis of products.
"Customer master data in ERP, history reasons not in $C R M$ ". Those who did not have CRM had customer master data in ERP. Supplier-vendor data were typically in CRM if one was used. IoT data were also utilized, but many were just starting the wider application, and some had legal restrictions for the use. Even though cost data would often be in ERP, the structural support by the product structure is not enough with the current logic of how the structure is utilized in the companies. Added consistency would be needed for product level analysis. The current reality is expressed as: "Difficulties in consolidating data from different systems". The somewhat siloed enterprise application landscape is not the only challenge, but data are sometimes outside: "Data in PPT, Excel, people's heads". Finding 3: Product level analysis and reporting on company products, based on facts, necessitates considering the overall logic of the enterprise application landscape and the use of data.

\section{DISCUSSION}

Fact-based analysis of company products necessitates structure to have the possibility to utilize data in a consistent manner. Structure is necessary for both, the technical perspective, but also the commercial. The consistency on the technical side supports, for example, understanding the cost of each version of the sold items. Cost structure is influenced by the nature of the product. Physical structure is represented by assemblies and components, service by processes, resources and cost drivers, and software by SW specific elements and resources. The technical structure may change during the active sales of the products due to quality improvement efforts, or pressures to reduce costs. Hence a consistent logic for new versions must exist. Consistent technical product structure may enable better product analysis at different levels of the technical structure.

Consistency on the commercial side is also necessary, not only to better link company products to customer value, but to have effective frame for fact-based analysis of products. For example, the sales price links to the sales items, or the product configurations. Comparing sales information and the corresponding cost information enables understanding product level profitability. The pricing logic can vary. Hence, product level analysis necessitates also the commercial structure. This study indicates that companies are not utilizing the commercial structure effectively.

The aim of the consistent product structure and the related master data is to reach data consistency that allows fact-based analysis. The company landscape of enterprise applications, the IT systems affects how data are available. The applications and the underlying requirements are not identical among companies. Also, the enterprise applications are often utilized in silos due to their functional roles, and the data are not well utilized. Hence, data must be considered at a higher level to have 
the possibility to gain additional benefits. For this reason, data should not be dependent on specific enterprise applications. Data should be structured in the applications in a consistent manner to better enable their utilization (Fig.1). The technical product structure and the related master data can reside in PDM or ERP based on company logic. These data can then be copied to be used by other applications. Companies should also have a clear location for the commercial product structure and related master data. The commercial structure does not need to be managed in the same place as the technical, but crucially, these two must be linked.

The data must be possible to relate to a structure in a consistent manner to support fact-based analysis and decision making. Business data is obtained from relevant locations and utilized for analysis, the product structure acting as the backbone. The data must be trustworthy and correspond to reality. Productization and the product structure logic can be ensured starting already during the design of products. The needed requirements and parameters can be linked to the products in a meaningful way. It is necessary that companies define and understand data, including product master data, and product-related business data. Fig. 2 depicts linking of master data to the commercial product structure and suitable enterprise applications. The necessary requirements link to the design, and parameters link to the later BOM configurations. Also, stakeholders can be linked to each of these. Data-related responsibilities might also be another aspect that could be guided structurally.

\section{A. Managerial Implications}

This study highlights the importance of understanding company products. Fact-based analysis and decisions on company products, and the wider utilization of one of the underused company assets, the data can be supported by productization and consistent product structure. Managers need to understand the significance of the commercial structure and the technical structure, and how these two must be interlinked to enable fact-based analysis of products. The traditional consideration of technical structure is not enough as the commercial and technical



Fig. 2. Linking master data to commercial product structure and enterprise applications. perspectives combine the sales and cost structures of products. These form the necessary backbone for data and their effective utilization. The company enterprise applications will have their functional role also in the future, but the data has additional potential for fact-based analysis. The data consistency allows effective analysis.

\section{REFERENCES}

[1] S. Maitlis, H. Ozcelik, "Toxic decision processes: a study of emotion and organizational decision making", Org. Science, vol. 15 , no. 4, pp. 375-393, 2004.

[2] S. Rajegopal, What is portfolio management, what are the trends and benefits?, In: Portfolio Management. Palgrave Macmillan, London, 2013, ch. 6, pp. 67-81.

[3] A. McAfee, E. Brynjolfsson, "Big data: the management revolution", Harv. Bus. Rev., pp. 61-68, October, 2012.

[4] N. Lahtinen, E. Mustonen, J. Harkonen, "Commercial and Technical Productization for Fact-Based Product Portfolio Management Over Lifecycle", IEEE Trans. Eng. Manage., in press.

[5] P. Weill, S.L. Woerner, "Is your company ready for a digital future?", MIT Sloan Man. Rev., vol. 59, no. 2, pp. 21-25, 2018.

[6] P. Aiken, J. Billings, Monetizing data management: finding the value in your organization's most important asset, Technics Publications, Basking Ridge, NJ, 2013.

[7] J. Li, F. Tao, Y. Cheng, L. Zhao, "Big data in product lifecycle management", Int. J. Adv. Manuf. Technol., vol. 81, no.1-4, pp. 667-684, 2015.

[8] F. Ameri, D. Dutta, "Product lifecycle management: closing the knowledge loops", Comp.-Aided Design \& Appl., vol. 2, no. 5, pp. 577-590, 2005.

[9] H. Hannila, A. Tolonen, J. Harkonen, H. Haapasalo, "Product and supply chain related data, processes and information systems for product portfolio management", Int. J. Prod. Lifecycle Manage., in press.

[10] R. Silvola, A. Tolonen, J. Harkonen, H. Haapasalo, T. Mannisto, "Defining one product data for a product, international", J. Bus. Inf. Sys., vol. 30, no. 4, pp. 489-520, 2019.

[11] J. Jeston, J. Nelis, Business process management. Practical guidelines to successful implementation, Routledge, New York, 2008.

[12] H. Kropsu-Vehkapera, H. Haapasalo, "Defining product data views for different stakeholders", J. Comp. Inf. Syst., vol. 52, no. 2, pp. 61-72. 2011.

[13] R. Silvola, O. Jaaskelainen, H. Kropsu-Vehkapera, H. Haapasalo, "Managing one master data - challenges and preconditions", Ind. Manage. \& Data Syst., vol. 111, no. 1, pp. 146-162, 2011.

[14] B. Otto, A. Reichert, "Organizing master data management: findings from an expert survey", in Proc.of . ACM Symp. Appl. Comput., New York, pp. 106-110, 2010.

[15] J. Harkonen, A. Tolonen, H. Haapasalo, "Service productisation: systematising and defining an offering", J. Service Manage., vol. 28, no. 5, pp. 936-971, 2017.

[16] A.K., Behera, A. McKay, F. Christopher, E.H. Chau, M.A Robinson, A. de Pennington, D.C. Hogg, "Sharing design definitions across product life cycles", Res. Eng. Design, vol.30, no.2, pp.339-361, 2019.

[17] D. Svensson, J. Malmqvist, "Strategies for product structure management at manufacturing firms", J. Comput. Inf. Sci. in Eng., vol. 2 , no. 1 , pp. 50-58, 2002.

[18] N., Orfi, J. Terpenny, S.S. Asli, "Harnessing product complexity: step 1 - establishing product complexity dimensions and indicators", The Eng. Economist, vol. 56, no. 1, pp. 59-79, 2011.

[19] J., Harkonen, H., Haapasalo, K. Hanninen, "Productisation: a review and research agenda", Int. J. Prod. Econ., vol. 164, pp. 65$82,2015$.

[20] K. Eisenhardt, "Building theories from case study research", Acad. Manage. Rev., vol. 14, no. 4, pp. 532-550, 1989.

[21] E. Bell, A. Bryman, B. Harley, Business Research Methods, 5th ed. Oxford: Oxford University Press, 2018. 